\title{
BRAND EXPERIENCE, BRAND COMMITMENT, DAN BRAND LOYALTY PENGGUNA APPLE IPHONE DI SURABAYA
}

\author{
Hatane Semuel*, Reynaldi Susanto Putra \\ Fakultas Ekonomi, Universitas Kristen Petra \\ Jl. Siwalankerto 121-131, Surabaya 60236 \\ *Korespondensi: E-mail: samy@ petra.ac.id
}

\begin{abstract}
Abstrak:Perkembangan teknologi dalam era globalisasi semakin pesat, sehingga menimbulkan persaingan yang tinggi antar perusahaan. Perusahaan smartphone umumnya berusaha untuk mempertahankan kelangsungan hidup, memperoleh profit yang optimal serta memperkuat brand di benak konsumen.Untuk mencapai tujuan tersebut maka produk yang dihasilkan perusahaan harus berguna, bermutu dan inovatif.Penelitian ini bertujuan untuk menganalisa pengaruh dari Brand Experience - Commitment terhadap brand loyalty pada pengguna Apple IPhone di Surabaya.Penelitian ini di laksanakan dengan menyebarkan kuisioner pada 100 responden pada pengguna Apple IPhone di Surabaya.Jenis penelitian ini menggunakan deskriptif kausal dengan menggunakan pengelolahan data dari SPSS dan SmartPLS. Hasil penelitian ini menunjukan bahwa pengaruh langsung brand experience terhadap brand loyalty tidak berpengaruh signifikan, sedangkan pengaruh tidak langsung pada brand experience terhadap brand loyalty melalui affective commitment memiliki pengaruh yang signifikan.
\end{abstract}

Kata kunci: Brand experience, brand commitment, brand loyalty.

\begin{abstract}
The development of technology in the era of globalization more rapidly, that causing high competition between companies. Smartphone companies generally strive to maintain survival, gain optimal profit and strengthen the brand in the minds of consumers. To achieve these objectives then the products produced company must be useful, quality and innovative. This research objective to analyze the impact of brand experience - commitment to brand loyalty to Apple IPhone users in Surabaya. This study was carried out by distributing questionnaires to 100 respondents on Apple IPhone users in Surabaya. This type of research uses descriptive causal using data management from SPSS and SmartPLS. The results of this study indicate that the direct influence of brand experience on brand loyalty has no significant effect, while indirect influence on brand experience on brand loyalty through affective commitment has a significant influence.
\end{abstract}

Keywords: Brand experience, brand commitment, brand loyalty.

\section{PENDAHULUAN}

Perkembangan teknologi dalam era globalisasi semakin pesat, sehingga menimbulkan persaingan yang tinggi antar perusahaan.Perusahaan smartphone umumnya berusaha untuk mempertahankan kelangsungan hidup, memperoleh profit yang optimal serta memperkuat brand di benak konsumen.Untuk mencapai tujuan tersebut maka produk yang dihasilkan perusahaan harus berguna, bermutu dan inovatif. Berbagai macam merek yang ada di Indonesia, membuat konsumen semakin selektif dalam memilih merek yang sesuai dengan yang diinginkannya.Salah satu merek yang ada di Indonesia yang cukup dikenal saat ini yaitu IPhone. Merek IPhone berasal dari Apple inc, sebuah perusahaan multinasional yang berpusat di Silicon Valley, Cupertino, California dan bergerak dalam bidang perancangan, pengembangan, dan penjualan smartphone. IPhone terus berinovasi dalam menciptakan produk-produk berkualitas dan canggih yang memenuhi kebutuhan masyarakat modern saat ini.Minat masyarakat Indonesia baik dari kalangan ekonomi menengah sampai ekonomi atas tidak takut untuk membeli IPhone yang harganya terbilang cukup mahal dan tidak ada diskon yang diberikan. Untuk menghasilkan brand experience, seseorang harus mempunyai pengalaman yang baik dengan suatu merek, sebagian besar dari mereka akan membeli produk atau layanan tersebut lagi dibanding membeli brand pesaing (Brakus et al., 2009, p.29). Kusuma (2014, p.9) mengatakan semakin baik brand experience yang dibentuk suatu merek maka semakin baik pula kesetiaan merek di mata konsumen, begitu juga sebaliknya. Hal ini dikarenakan brand experience membantu mengembangkan hubungan cognitive dan affective diantara sebuah merek dan diri konsumen, dimana konsumen akan mengingat pengalaman yang mengesankan dari merek tersebut (Dolbec \& Chebat, 2013, p.462). Pengalaman dapat terjadi secara tidak langsung seperti ketika konsumen melihat iklan dan komunikasi pemasaran. Tetapi kebanyakan pengalaman terjadi secara langsung ketika konsumen berbelanja, membeli, dan mengkonsumsi produk

Pengalaman konsumen yang memuaskan dapat mempengaruhi afektif konsumen (Oliver, 1999, p. 35). Pengalaman masa lalu dapat memberikan ingatan emosi yang bisa berdampak pada perilaku.Kemudian perilaku tersebut diulang sehingga menjadi kebiasaan karena pengalaman emosional masa lalu 
tersebut.Pada pengguna smartphone, pengalaman bisa terjadi ketika konsumen menggunakan sebuah smartphone dan menyukainya.Hal itu bisa menimbulkan minat untuk pembelian berikutnya, dikarenakan individu dalam suasana hati yang baik cenderung lebih mudah puas daripada ketika suasana hati buruk. Suasana lingkungan mempengaruhi suasana hati yang baik sehingga memperkuat hubungan sikap dan tingkah laku (Dick \& Basu, 1994, p.104).

Affective commitment menjadi komponen emosional, dan telah menerima lebih banyak perhatian dari para peneliti dari continuance commitment dalam beberapa tahun terakhir. Menurut Fullerton (2005) affective commitment memediasi experience dan loyalty. Serta Evanschitzky et al (2006) berpendapat bahwa, mengingat pembeli dan penjual di pasar konsumen sering memiliki beberapa alternatif yang tersedia untuk mereka, serta biaya peralihan produk rendah, maka affective commitment umumnya memiliki dampak yang lebih besar pada brand loyalty dari continuance commitment.

Dick dan Basu (1994) mengklasifikasikan loyalitas dalam berbagai jenis dan mendirikan konsep benar dari brand loyalty, yang menggabungkan unsur-unsur sikap positif, terlepas dari pembelian kembali yang konsisten. Bloemer dan Kasper (1995, p 314) mendukung argumen ini dan juga sepakat bahwa perbedaan utama antara kesetiaan yang benar dan palsu adalah bahwa komitmen merupakan kondisi yang diperlukan untuk terjadinya brand loyalty. Disini perlu dicatat bahwa, meskipun komitmen, sebagai sebuah konsep yang telah sering digunakan secara sinonim dengan loyalitas karena kedekatannya (Li dan Petrick, 2010). Dalam hal ini, beberapa penulis telah menyarakan bahwa affective commitment adalah penentu utama untuk pengembangan pada true brand loyalty (Amine, 1998; Mattila, 2001; Punniyamoorthy dan Prasanna, 2007).

Bagi perusahaan memiliki pelanggan yang loyal atau setia terhadap merek yang dipasarkan merupakan sasaran yang ingin dicapai dalam jangka panjang. Konsumen yang loyal akan memberikan kenaikan profitabilitas bagi perusahaan. Selain membeli kembali, konsumen yang loyal juga akan melakukan word of mouth dan meyakinkan konsumen lain sehingga dapat menjadi pemasar bagi konsumen baru. Hal ini tentu akan mengurangi biaya pemasaran perusahaan (Dick \& Basu, 1994, p.111). Oleh karena itu, perusahaan akan berusaha menggunakan berbagai strategi yang bisa mempertahankan konsumennya agar tidak berpindah ke merek lain (Istijanto, 2005, p.172).

Brand Loyalty diukur dengan menggunakan faktor-faktor seperti urutan pembelian, persentase dari total pembelian, probabilitas pembelian (Kumar dan Advani, 2005; Kabiraj dan Shanmugan, 2011; Iglesias et al, 2011). Gagasan ini menyebabkan fokus pada harga, fungsi, dan kualitas ketika memasarkan produk dan jasa, dengan harapan pelanggan dapat mengembangkan pembelian berulang jika faktorfaktor ini memenuhi kriteria pelanggan, beberapa peneliti seperti Cunningham (1967), Hari (1969) dan Jacoby (1971), mulai menyadari bahwa aspek sikap brand loyalty sama pentingnya dengan aspek perilaku.

Dengan berbagai penjelasan yang dikemukakan sebelumnya, penelitian ini bertujuan untuk menjelaskan tentang faktor-faktor yang mempengaruhi brand loyalty, serta ingin menjelaskan bagaimana hubungan antara pengalaman dan brand commitment yang dapat mempengaruhi brand loyalty.

Penelitian ini akan mengambil obyek pengguna IPhone di Surabaya.Berdasarkan latar belakang tersebut, maka penelitian ini berusaha mengetahui dan menganalisis faktor-faktor yang mempengaruhi brand loyalty dengan variabel brand experience dan brand commitment.

\section{TINJAUAN PUSTAKA}

\section{Brand Experience}

Menurut Brakus et al. (2009) Brand experience didefinisikan sebagai sensasi, perasaan, kognisi dan tanggapan konsumen yang ditimbulkan oleh merek, terkait rangsangan yang ditimbulkan oleh desain merek, identitas merek, komunikasi pemasaran, orang dan lingkungan merek tersebut dipasarkan. Untuk dapat mendefinisikan lebih jauh mengenai brand experience Brakus et al. (2009) memulai penelitian dengan melihat sudut pandang konsumen dengan menguji pengalaman-pengalaman konsumen itu sendiri dan bagaimana pengalaman itu menghasilkan pendapat sikap, dan aspek lainnya dari perilaku konsumen. Brand experience dimulai pada saat konsumen mencari produk,membeli,menerima pelayanan dan mengkonsumsi produk. Brand experience dapat dirasakan secara langsung maupun secara tidak langsung saat konsumen melihat iklan atau juga saat pemasar mengkomunikasikan produk melalui website. Menurut Brakus et al. (2009) terdapat 4 dimensi brand experience:

1. Sensorik; menciptakan pengalaman melalui penglihatan, suara, sentuhan, bau dan rasa.

2. Afeksi; pendekatan perasaan dengan mempengaruhi suasana hati, perasaan dan emosi.

3. Perilaku; menciptakan pengalaman secara fisik, pola perilaku, gaya hidup. 
4. Intelektual; menciptakan pengalaman yang mendorong konsumen terlibat dalam pemikiran seksama mengenai keberadaan suatu merek

\section{Affective Commitment}

Menurut Amine (1988), Affective commitment mencerminkan sejauh mana konsumen ingin mempertahankan hubungan dengan merek berdasarkan ikatan emosional mereka untuk merek. Fenomena ini termasuk sejauh mana konsumen mengidentifikasi sebuah merek, dan merupakan inti dari hubungan consumer-brand (Louis dan Lombart, 2010). Selanjutnya, Bansal et al., (2004) menjelaskan bahwa affective commitment berpusat pada keterikatan emosional konsumen terhadap merek, identifikasi mereka dengan merek, dan keterlibatan mereka dengan merek. Ketiga faktor tersebut akan menyebabkan keinginan untuk menjaga hubungan dengan merek.

\section{Brand Loyalty}

Menurut Schiffman dan Kanuk (2009), brand loyalty adalah preferensi konsumen secara konsisten untuk melakukan pembelian pada merek yang sama pada produk yang spesifik atau kategori pelayanan tertentu. Brand loyalty adalah sebuah komitmen yang kuat dalam berlangganan atau membeli suatu merek secara konsisten di masa yang akan datang.

Durianto et al. (2004, pp.132-133) menjelaskan bahwa brand loyalty dapat diukur melalui:

1. Behavior measures; merupakan cara untuk menentukan loyalitas terutama untuk tingkat habitual behavior (perilaku kebiasaan) melalui perhitungan pola pembelian yang aktual. Berikut beberapa ukuran yang dapat digunakan:

a. Tingkat pembelian ulang; tingkat persentase pelanggan yang membeli kembali merek yang sama pada jenis produk tersebut.

b. Persentase pembelian; persentase pelanggan untuk setiap merek yang dibeli dari beberapa pembelian terakhir.

c. Jumlah merek yang dibeli; tingkat persentase pelanggan dari suatu produk untuk hanya membeli satu merek, dua merek, dan seterusnya.

2. Measuring switch cost; pada umumnya jika biaya untuk mengganti merek sangat mahal, konsumen akan enggan untuk berganti merek sehingga tingkat peralihan produk rendah.

3. Measuring satisfaction; bila ketidakpuasan konsumen terhadap suatu merek rendah, maka pada umumnya tidak cukup alasan bagi pelanggan untuk berpindah ke merek lain kecuali bila ada faktor-faktor penarik lain yang cukup kuat.

4. Measuring liking brand; kesukaan terhadap merek, kepecayaan, perasaan hormat atau bersahabat dengan suatu merek akan memberikan kedekatan dan perasaan hangat kepada konsumen. Akan sulit bagi merek lain untuk menarik pelanggan yang berada dalam tahap ini. Ukuran rasa suka tersebut adalah kemauan untuk membayar harga yang lebih mahal untuk mendapatkan produk tersebut.

5. Measuring commitment, memperhitungkan jumlah interaksi dan komitmen konsumen terkait dengan produk tersebut. Kesukaan konsumen akan suatu merek akan mendorong mereka untuk membicarakan merek tersebut kepada orang lain baik dalam taraf menceritakan atau sampai tahap merekomendasikan.

\section{Kerangka Konseptual}

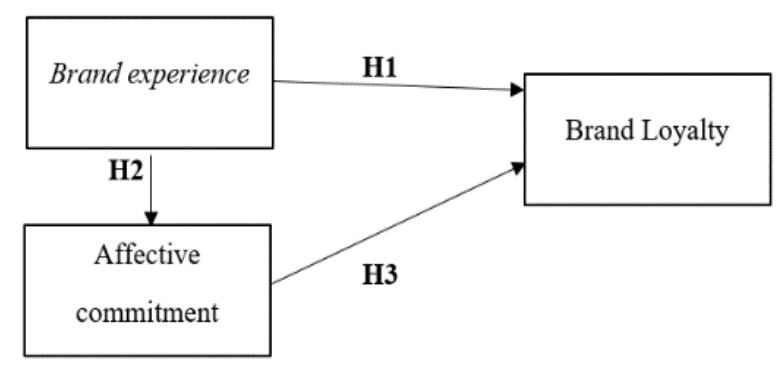

Gambar1. Kerangka Konseptual

\section{Hipotesa}

H1: Brand experience memiliki hubungan positif dengan brand loyalty

$\mathrm{H} 2$ : Brand experience memiliki hubungan positif dengan affective commitment, dan affective commitment merupakan variabel mediasi.

$\mathrm{H} 3$ : Affective commitment memiliki hubungan positif dengan brand loyalty

\section{METODE PENELITIAN}

\section{Populasi dan Sampel}

Populasi penelitian ini adalah seluruh konsumen yang merupakan pengguna Iphone di Surabaya. Jumlah responden yang akan diambil oleh peneliti agar dihasilkan sampling eror $10 \%$ dengan tingkat percayaan $95 \%$ adalah sebesar 100 responden dimana menurut Bahri \& Zamzam (2014, p.11) ukuran sampel sebaiknya berkisar antara 100-200 responden dan dianggap sudah cukup mewakili populasi. 


\section{Definisi Operasional Variabel}

\section{Brand Experience $(\mathrm{X} 1)$}

Brand Experience adalah pengalaman konsumen ketika berinteraksi dengan produk IPhone di Surabaya.Brand experience menurut Brakus et al. (2009) dapat diukur dengan empat dimensi ukuran, yaitu sensorik, afeksi, perilaku, dan intelektual. Dalam penelitian ini indikator-indikator yang digunakan sebagai berikut: Sensorik; pengalaman konsumen melalui panca indera; Afeksi; pengalaman terhadap merek yang mempengaruhi suasana hati dan konsumen, Perilaku; pengalaman terhadap merek membuat konsumen untuk melakukan sesuatu/mengubah perilaku, dan intelektual.

\section{Affective Commitment (X2)}

Bansal et al. (2004) menjelaskan bahwa affective commitment berpusat pada keterikatan emosional konsumen terhadap merek, identifikasi mereka dengan merek, dan keterlibatan mereka dengan merek. Dalam penelitian ini indikator-indikator yang digunakan adalah: emosional, identifikasi, dan keterlibatan.

\section{Brand Loyalty $(\mathrm{Y})$}

Durianto et al. (2004, p.132-133) menjelaskan bahwa brand loyalty dapat diukur melalui:

a. Behaviour measure;merupakan cara untuk menentukan loyalitas terutama untuk tingkat habitual behavior (perilaku kebiasaan) melalui perhitungan pola pembelian yang aktual.

b. Measuring switch cost; pada umumnya jika biaya untuk mengganti merek sangat mahal, konsumen akan enggan untuk berganti merek sehingga tingkat peralihan produk rendah.

c. Measuring satisfaction; bila ketidakpuasan konsumen terhadap suatu merek rendah, maka pada umumnya tidak cukup alasan bagi pelanggan untuk berpindah ke merek lain kecuali bila ada faktor-faktor penarik lain yang cukup kuat.

d. Measuring liking brand; Kesukaan terhadap merek, kepecayaan, perasaan hormat atau bersahabat dengan suatu merek akan memberikan kedekatan dan perasaan hangat kepada konsumen. Akan sulit bagi merek lain untuk menarik pelanggan yang berada dalam tahap ini. Ukuran rasa suka tersebut adalah kemauan untuk membayar harga yang lebih mahal untuk mendapatkan produk tersebut. e. Measuring commitment, memperhitungkan jumlah interaksi dan komitmen konsumen terkait dengan produk tersebut. Kesukaan konsumen akan suatu merek akan mendorong mereka untuk membicarakan merek tersebut kepada orang lain baik dalam taraf menceritakan atau sampai tahap merekomendasikan.

\section{Statistik Deskriptif}

Statistik deskriptif adalah statistik yang digunakan untuk menganalisa data dengan cara mendeskripsikan data yang telah terkumpul sebagaimana adanya tanpa bermaksud membuat kesimpulan yang berlalu untuk umum atau generalisasi (Sugiyono, 2010 , p. 206). Pengukuran rata-rata atau mean digunakan untuk mengukur nilai sentral suatu distribusi data berdasarkan nilai rata-rata yang dihitung dengan cara membagi nilai hasil penjumlahan sekelompok data dengan jumlah data yang diteliti. Sedangkan crosstab (tabulasi silang) adalah sebuah tabel silang yang terdiri atas satu baris atau lebih dan satu kolom atau lebih (Anshori \& Iswati, 2009, p.117).

Setelah mean diketahui, rentang skala diperlukan untuk menentukan kategori mean yang diperoleh termasuk ke dalam kelas interval yang mana. Untung menghitung rentang skala, dapat memakai rumus (Durianto et al. 2004, p.43) sebagai berikut:

$$
\mathrm{RS}=\frac{\mathrm{m}-\mathrm{n}}{\mathrm{b}}
$$

\section{Uji Validitas dan Reliabilitas}

Validitas dalam penelitian digunakan untuk mengukur sah/valid tidaknya suatu kuesioner. Validitas merupakan sebuah ukuran yang menunjukkan sejauh mana instrument pengukur mampu mengukur apa yang ingin diukur. Koefisien relasi antara skor suatu indikator dengan skor total seluruh indikator $\geq$ 0,197 ( $\mathrm{N}=100)$, maka instrument dianggap valid. Menurut Cooper dalam Umi Narimawati (2010:43), reliabilitas adalah: "Reliability is a characteristic of measurement concerned with accuracy, precision, and consistency". Reliabilitas merupakan salah satu ciri atau karakter utama instrumen pengaruh yang baik.Berdasarkan hal tersebut, maka setelah melakukan pengujian validitas, langkah selanjutnya adalah melakukan pengujian reliabilitas untuk menguji kecenderungan atau kepercayaan alat pengukuran dengan diperoleh nilai $r$ dari pengujian reliabilitas yang menunjukan hasil indeks korelasi yang menyatakan ada tidaknya hubungan antara dua belah instrument. 


\section{Partial Least Square}

Partial Least Square (PLS) dikembangkan pertama kali oleh Herman Wold (1982). Ada beberapa metode yang dikembangkan berkaitan dengan PLS yaitu model PLS Regression (PLS-R) dan PLS Path Modeling (PLS-PM). PLS Path Modeling dikembangkan sebagai variable pemodelan persamaan variable (SEM) yang dasar teorinya lemah.PLS-PM berbasis varian berbeda dengan metode SEM dengan software AMOS, Lisrel EQS menggunakan basis kovarian.

\section{Outer Model}

Model ini menspesifikasi hubungan antar variabel laten dengan indikator-indikatornya. atau dapat dikatakan bahwa outer model mendefinisikan bagaimana setiap indikator berhubungan dengan variabel latennya. Uji yang dilakukan pada outer model:

1. Convergent Validity. dari model pengukuran dengan refleksif indikator dinilai berdasarkan korelasi antara item score/component score dengan construct score yang dihitung dengan PLS. Chin (1998) yang dikutip oleh Ghozali (2008) mengatakan ukuran refleksif individual dikatakan tinggi jika berkorelasi lebih dari 0.70 dengan konstruk yang ingin diukur. Namun untuk penelitian tahap awal dari pengembangan skala pengukuran nilai loading 0.50 sampai 0.60 dianggap cukup.

2. Discriminant Validity. Nilai ini merupakan nilai cross loading factor yang berguna untuk mengetahui apakah konstruk memiliki diskriminan yang memadai yaitu dengan cara membandingkan nilai loading pada konstruk yang dituju harus lebih besar dibandingkan dengan nilai loading dengan konstruk yang lain selain itu juga dapat dilihat dari membandingkan akar AVE dengan nilai korelasi antar variabel. Jika nilai korelasi lebih kecil dari nilai akar AVE berarti telah memenuhi discriminantvalidity.

3. Composite Reliability. Data yang memiliki composite reliability $>0.7$ mempunyai reliabilitas yang tinggi.

4. Average Variance Extracted (AVE). Nilai AVE yang diharapkan $>0.5$.

5. Cronbach alpha. Uji reliabilitas diperkuat dengan cronbach alpha. Nilai diharapkan $>0.6$ untuk semua konstruk.

\section{Inner Model}

Uji pada model struktural dilakukan untuk menguji hubungan antara konstruk laten. Ada beberapa uji untuk model struktural yaitu:
1. $R$ Square pada konstruk endogen. Nilai R Square adalah koefisien determinasi pada konstruk endogen.

2. Estimate for Path Coefficients, merupakan nilai koefisen jalur atau besarnya hubungan konstruk laten. Dilakukan dengan prosedur Bootrapping.

3. Prediction relevance ( $Q$ square) atau dikenal dengan Stone-Geisser's. Uji ini dilakukan untuk mengetahui kapabilitas prediksi dengan prosedur blindfolding.

\section{Uji Hipotesis}

Model structural atau inner model dievaluasi untuk melihat adanya hubungan variabel eksogen ke variabel endogen serta menggunakan $R$-square untuk konstruk dependen.Model structural atau inner model dievaluasi dengan melihat presentase varian yang dijelaskan, yaitu dengan melihat R2 pada konstruk variabel dependen dengan menggunakan pengukuran $R$-square test. Stabilitas dari estimasi ini dievaluasi dengan menggunakan $t$-test, dan pengaruh positif dan negatifnya dapat dilihat dari original sample yang didapat dari prosedur bootstrapping.

Setelah dilakukan fit test dan analisa partial least square untuk melihat nilai regresi dari tiap-tiap konstruk, dilakukan bootstrap untuk melihat apakah terdapat hubungan yang signifikan antara variabel yang diamati. Nilai bootstrap $>=1,96$ menunjukkan bahwa pengaruh variabel tersebuat kuat, sedangkan apabila nilainya dibawah 1,96, maka pengaruhnya lemah.

\section{ANALISA DAN PEMBAHASAN}

\section{Statistik Deskriptif}

Penelitian ini peneliti mengambil 100 responden di Surabaya.Hasil menunjukan bahwa mayoritas responden adalah wanita dengan jumlah sebanyak 56 orang.Responden mayoritas berusia $<20$ tahun dengan jumlah 54 sebanyak 54 orang dan memiliki pekerjaan sebagai pelajar/mahasiswa.Durasi menggunakan IPhone terbanyak ialah > 3 tahun dengan jumlah sebesar 48 orang. Hasil analisa deksriptif terhadap indikator brand experience dan affective commitment terhadap brand loyaltyakan dipaparkan dengan penjelasan sebagai berikut:

1. Dimensi yang termasuk kategori tinggi pada kisaran mean3,41 - 4,20 yaitu: dimensi keterlibatan dan indikator brand loyalty dengan nilai mean sebesar 4.01 dan 4.16

2. Dimensi yang termasuk kategori sangat tinggi pada kisaran mean 4,21 - 5,00 yaitu: dimensi 
sensorik dengan nilai mean 4.48 , dimensi afeksi dengan nilai mean 4.46 , dimensi perilaku dengan nilai mean 4.28 , dimensi intelektual dengan nilai mean 4.40, dimensi emosional dan identifikasi dengan nilai mean sebesar 4.38 dan 4.24.

3. Semua item pertanyaan pada variabel brand experience, affective commitment, dan brand loyalty memiliki $r$ hitung $>r$ tabel 0,197 , sehingga item-item pertanyaan yang mengukur variabel penelitian dinyatakan valid.

4. Variabel brand experience, affective commitment, dan brand loyalty memiliki nilai cronbach alpha $>$ 0,6 , sehingga item-item pertanyaan yang mengukur variabel penelitian dinyatakan reliabel.

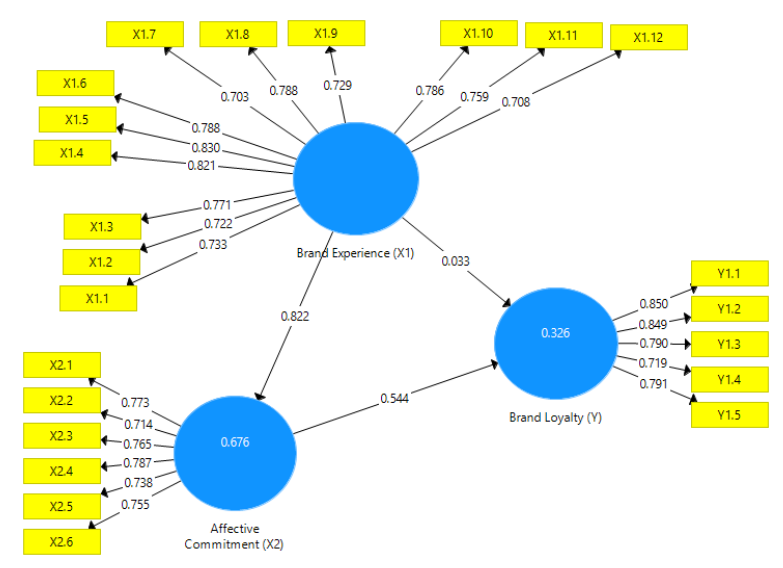

Gambar2.Koefisien Jalur

\section{Outer Model}

Analisa Partial Least Square (PLS), dijabarkan evaluasi kofesien jalur terkait Outer model pada penelitian ini sebagai berikut:

1. Hasil indikator pada variabel brand experience dan affective commitment terhadap brand loyalty memiliki loading factor lebih besar dari 0.70 , sehingga indikator-indikator tersebut telah memenuhi convergent validity. Hal ini berarti, semua indikator dapat digunakan untuk analisis lebih lanjut.

2. Indikator yang paling berpengaruh pada dimensi sensorik adalah IPhone memiliki ciri khas pada pernyataan X1.3 (0.771).

3. Untuk dimensi afeksi, indikator yang paling tinggi adalah menggunakan IPhone memberikan kepuasan pada pernyataan X1.5 (0.830).

4. Sedangkan untuk dimensi perilaku, indikator yang paling tinggi pengaruhnya adalah menggunakan IPhone dalam melakukan aktivitas sehari-hari pada pernyataan X1.8 (0.788).

5. Sementara unuk dimensi intelektual, indikator yang menunjukan pengaruh paling tinggi adalah
IPhone merupakan smartphone yang berkualitas $\mathrm{X} 1.10$ (0.786).

6. Dimensi emosional, indikator yang memiliki pengaruh paling tinggi adalah X2.1 merek IPhone sudah membekas di hati sehingga tidak tertarik berpindah ke merek lain (0.773).

7. Dimensi identifikasi, indikator yang paling tinggi adalah X2.4 ketika seseorang memuji merek Apple IPhone, rasanya seperti pujian pribadi (0.787).

8. Dimensi keterlibatan, X2.6 saya pikir adanya perbedaan yang spesifik antara merek Apple IPhone dengan merek smartphone lainnya (0.755) yang memiliki pengaruh yang paling tinggi.

9. Indikator tertinggi dari brand loyalty ialah Y1.1 saya akan setia menjadi pengguna IPhone (0.850).

\section{Discriminant Validity dan Composite Reliability}

Masing-masing indikator pada variabel penelitian memiliki nilai cross loading terbesar pada variabel yang dibentuknya dibandingkan pada variabel lainnya. Dengan demikian bisa dikatakan indikatorindikator yang digunakan dalam penelitian ini telah memiliki discriminat validity yang baik dalam menyusun variabelnya masing-masing.Nilai AVE semua variabel $>0.5$. Nilai composite reliability semua variabel penelitian $>0,7$. Hasil ini menunjukkan bahwa masing-masing variabel telah memenuhi composite reliability sehingga dapat disimpulkan bahwa keseluruhan variabel memiliki level internal consistency reliability yang tinggi.

\section{Inner Model}

Evaluasi path coefficient digunakan untuk menunjukkan seberapa kuat efek atau pengaruh variabel independen kepada variabel dependen.Sedangkan coefficient determination digunakan untuk mengukur seberapa banyak variabel endogen dipengaruhi oleh variabel lainnya. Didalam marketing research, nilai R2 diatas 0,75 keatas dikategorikan substansial, 0,50 $-0,75$ artinya sedang, dan $0,25-0,50$ artinya lemah.

Tabel1. Koefisien Path dan Hasil Uji Pengaruh

\begin{tabular}{|l|l|l|l|}
\hline & $\begin{array}{c}\text { Koefisien } \\
\text { Path }\end{array}$ & t-statistic & $\begin{array}{c}\text { P- } \\
\text { Values }\end{array}$ \\
\hline Brand Experience > Brand Loyalty & 0.033 & 0.195 & 0.846 \\
\hline Brand experience > Affective Commitment & 0.822 & 13.497 & 0.000 \\
\hline Affective Commitment > Brand Loyalty & 0.544 & 4.564 & 0.000 \\
\hline
\end{tabular}

Pengaruh langsung pada brand experience terhadap brand loyalty yang dijelaskan oleh nilai path 
coefficient sebesar 0.033.Data menunjukan bahwa pengaruh tidak signifikan pada variabel ini.Pengaruh Tidak langsung pada brand experience terhadap brand loyalty melalui affective commitment ialah memiliki nilai path coefficient sebesar 0.822. Data menunjukan bahwa ada pengaruh signifikan antara brand experience dan affective commitment. Pengaruh total dari brand experience dan affective commitment terhadap brand loyalty sebesar $(0.822 \times 0.544=$ 0.447). Data menunjukan bahwa adanya pengaruh signifikan pada variabel brand experience terhadap brand loyalty apabila menggunakan affective commitment sebagai variabel mediasi

\section{Uji Goodness of Fit}

Berdasarkan pengolahan data dengan PLS, dihasilkan nilai R-Square sebagai berikut: Nilai Rsquare untuk affective commitment adalah sebesar 0.676 memiliki arti bahwa persentase besarnya pengaruh brand experience terhadap affective commitment adalah sebesar $67.6 \%$, Nilai R-square untuk brand loyalty sebesar 0.326 memiliki arti bahwa persentease pengaruh brand experience terhadap brand loyalty adalah sebesar $32.6 \%$.

Penilaian goodness-of-fit diketahui dari nilai $Q$ Square. Nilai $Q$-Square memiliki arti yang sama dengan koefisien determinasi (R-Square) pada analisis regresi, dimana semakin tinggi $Q$-Square, maka model dapat dikatakan semakin fit. berikut:

Hasil perhitungan nilai $Q$-Square adalah sebagai

$$
\begin{aligned}
Q-\text { Square } & =1-[(1-0.676) \times(1-0.326)] \\
& =1-(0.324 \times 0.674) \\
& =0.71
\end{aligned}
$$

Dari hasil perhitungan didapatkan nilai $Q$ Square sebesar 0,71, artinya besarnya keragaman dari data penelitian yang dapat dijelaskan oleh model penelitian adalah sebesar $71 \%$, sedangkan $29 \%$ sisanya dijelaskan faktor lain di luar model. Berdasarkan hasil ini, model pada penelitian telah memiliki goodness of fit yang baik.

\section{Uji Hipotesis}

Pengujian hipotesis penelitian dengan menggunakan analisis PLS dilakukan dengan menggunakan tabel inner weight. Hipotesis penelitian dapat diterima jika nilai $t$ hitung (t-statistic) $\geq \mathrm{t}$ tabel pada tingkat kesalahan $(\alpha) 5 \%$ yaitu 1,96 . Berikut adalah nilai koefisien path (original sample estimate) dan nilait hitung (t-statistic) pada inner model:

T-statistics pada pengaruh brand experience terhadap brand loyalty menunjukan angka 0.195 artinya tidak ada pengaruh dari brand experience terhadap brand loyalty.

T-statistics pada pengaruh brand experience terhadap affective commitment menunjukan angka 13.497, artinya terdapat pengaruh signifikan dari brand experience terhadap affective commitment.

$\mathrm{T}$-statistics pada pengaruh affective commitment terhadap brand loyalty menunjukan angka 4.564, artinya terdapat pengaruh signifikan dari affective commitment terhadap brand loyalty.

\section{KESIMPULAN}

Berdasarkan hasil analisis data yang telah dilakukan, maka kesimpulan untuk penelitian ini adalah sebagai berikut:

1. Brand experience berpengaruh negatif terhadap brand loyalty. Bahwa tidak ada pengaruh langsung dari brand experience terhadap brand loyalty.

2. Brand experience berpengaruh positif terhadap affective commitment, Semakin baik pengalaman seseorang terhadap suatu brand, maka semakin tinggi pula affective commitment terhadap suatu brand.

3. Affective commitment berpengaruh positif terhadap brand loyalty. Ketika konsumen memiliki sikap komitmen terhadap suatu merek, maka konsumen juga akan menjadi loyal terhadap merek tersebut. Semakin tinggi komitmen yang dimiliki konsumen maka akan menimbulkan loyalitas merek yang tinggi.

4. Brand experience memiliki pengaruh terhadap brand loyalty apabila variabel affective commitment merupakan variabel mediasi.

\section{DAFTAR PUSTAKA}

Amine, A. (1998).Consumers' true brand loyalty: the central role of commitment. Journal of Strategic Marketing, 6(4), pp. 305-319.

Anshori, Muslich \& Sri Iswati.(2009). Metodologi Penelitian Kuantitatif. Surabaya: Airlangga University Press (AUP)

Bahri S, Zamzam F. 2014. Model Penelitian Kuantitatif Berbasis SEM-AMOS. Yogyakarta (ID): Deepublish.

Bansal, H.S., Irving, P.G., \& Taylor, S.F. (2004).A three-component model of customer commitment to service providers. Journal of the Academy of Marketing Science, 32(3), pp. 234-250.

Bloemer dan J. Kasper. 1995. "The complex relationship between consumer satisfaction and brand loyalty". Journal of Economic Psychology, 16(2), pp.19-24. 
Brakus, J.J., Schmitt, B.H \& Zarantonello, L. (2009). "Brand Experience: What is it? How is it Meassured? Does it Affect Loyalty? Journal of Marketing, 73(2).

Bungin, Burhan, 2010. Penelitian Kualitatif: Komunikasi, Ekonomi, Kebijakan.

Cunningham, S.M. (1967). Perceived risk and brand loyalty. In Cox, D. (Ed.), Risk Taking and Information Handling in Consumer Behaviour. Boston, Harvard University Press.

Daymon, Christine, dan Immy Holloway. 2008. Metode-metode Riset Kualitatif: dalam Public Relations dan Marketing Communications. Yogyakarta: Penerbit Bentang.

Dick, A.S dan Basu, K., 1994, "Customer Loyalty: Toward an Integrated Conceptual Framework", Journal of The Academy Marketing Science, 22, pp. 99-113.

Dolbec, P.-Y., \& Chebat, J.-C. (2013). The Impact of a Flagship vs. a Brand Store on Brand Attitude, Brand Attachment and Brand Equity.Journal of Retailing, 89(4), pp. 460-466.

Durianto, Darmadi dkk. 2004. Brand Equity Ten, Strategi Memimpin Pasar. PT. Gramedia Pustaka Utama, Jakarta.
Jacoby, J. (1971, June). A model of multi-brand loyalty. Journal of Advertising Research, 11, 25-31.

Kumar, S.R., \& Advani, J., Y. (2005). Factors affecting brand loyalty: A study in an emerging market on fast moving consumer goods. Journal of Customer Behaviour, 4(2), 251-275.

Kusuma, Y.S. 2014, Pengaruh Brand Experience Terhadap brand Loyalty Melalui Brand Satisfaction dan Brand Trust Harley Davidson di Surabaya, Jurnal Manajemen Pemasaran, 2(1), pp. 1-11.

Louis, D., \& Lambart, C. (2010). Impact of brand personality on three major relational consequences (trust, attachment, and commitment to the brand). Journal of Product and Brand Management, 19(2), 114-130.

Oliver, R.L., 1999. Whence Consumer Loyalty, Journal of Marketing, 63, pp. 33-44.

Punniyamoorthy, M., \& Raj, P.M. (2007).An Empirical Model for Brand Loyalty Measurement. Journal of Targeting, Measurement and Analysis for Marketing, 15(4), pp. 222-233.

Schiffman, L, G. dan, L. L. Kanuk. 2009. Persepsi kualitas, Consumer Behavior. New Jersey: Perason Prestice Hall. 